\title{
Peningkatan Respon Imun Non Spesik Ikan Mas (Cyprinus carpio L) Melalui Pemberian Bawang Putih (Allium Sativum)
}

\section{(Enhancement of of Nonspecific immune response of carp (Cyprinus carpio L) throught oral administration of Allium Sativum)}

\author{
Kedis Lengka, Henky Manoppo, Magdalena E.F. Kolopita
}

\begin{abstract}
ABSTRAK
Penelitian ini bertujuan untuk menetapkan dosis bubuk bawang putih (Allium sativum) yang tepat yang mampu meningkatkan respon imun non spesifik secara optimal dan pertumbuhan pada ikan mas (Cyprinus carpio L). Hewan uji yang digunakan adalah ikan mas panjang 8-12 cm dan berat rata-rata 9.37 g yang diperoleh dari Balai Budidaya Ikan Air Tawar (BBAT) Tatelu.setelah aklimatisasi selama 2 minggu dalam bak fiber, ikan dipindahkan ke dalam akuarium kaca berukuran $80 \mathrm{~cm}$ x $40 \mathrm{~cm}$ x 40 cm (p x l x t) dengan kepadatan 15 ekor/akuarium dan setiap akuarium dilengkapi dengan aerator. Perlakuan bawang putih yang diberikan adalah $\mathrm{A}=0 \mathrm{~g}, \mathrm{~B}=10 \mathrm{~g}, \mathrm{C}=20 \mathrm{~g}, \mathrm{D}=30 \mathrm{~g}$, dan $\mathrm{E}=40 \mathrm{~g} / \mathrm{kg}$ pakan. Dosis pemberian 5\% dari berat badan/hari dengan frekuensi 2 kali sehari yaitu pukul 08.00 dan pukul 16.00 wita. Data yang dikumpulkan adalah parameter imun (TLC dan Aktivitas fagositosis). Data yang diperoleh dinyatakan dalam bentuk nilai rata-rata \pm Stdv dan pertumbuhan mutlak. Hasil penelitian menunjukkan bahwa pemberian bubuk bawang putih dengan dosis $30 \mathrm{~g} / \mathrm{kg}$ pakan dan diberikan selama satu bulan efektif meningkatkan respon imun non spesifik dan pertumbuhan mas.
\end{abstract}

Kata kunci: Bawang putih, Respon imun, Total leukosit, Aktivitas fagositosis.

\section{ABSTRACT}

This research aimed to determine the proper dose of white onion (Allium sativum) powder to stimulate the nonspecific immune response and growth of carp (Cyprinus carpio L). Fish (length 8-12 $\mathrm{cm}$; weight $9.37 \mathrm{~g}$ in average) were obtained from BBAT Tatelu (Freshwater Aquaculture Board). After acclimatized in 1000-l fibre tank for two weeks, fish were introduced to 15 glass aquaria (80x40x40 cm) equiped with aeration at a density of 15 fish/aquarium. Fish were fed diet supplemented with white onion powder at five different doses (0,10, 20, 30 and $40 \mathrm{~g} / \mathrm{kg}$ diet), twice daily at 5\%bw. Data collected included total leucocyte count (TLC), phagocytosis activity and growth of fish. Results showed that after four weeks of feeding, supplementation of white onion powder at 30 $\mathrm{g} / \mathrm{kg}$ diet was effective to enhance nonspecific immune response and growth of carp.

Keywords: Allium sativum, immune response, total leucocyte count, phagocytosis activity

\section{PENDAHULUAN}

Budidaya ikan yang dilaksanakan secara intensif berdampak negatif apabila tidak ditangani dengan baik terhadap usaha budidaya khususnya terhadap kesehatan ikan yang dipelihara. Tingginya padat tebar dan pakan yang digunakan menjadi pendorong bagi timbulnya penyakit akibat menurunnya kualitas air karena timbunan bahan organik dari sisa pakan maupun ekskresi ikan. Sementara itu ikan menjadi stress sehingga rentan terhadap serangan penyakit, khususnya penyakit infeksi seperti yang disebabkan oleh bakteri maupun virus (Afrianto dan Liviawaty, 2006). Oleh karena itu 
maka penanggulangan terhadap penyakit melalui upaya pencegahan menjadi hal yang penting.

Upaya pencegahan penyakit pada ikan dapat dilakukan dengan menggunakan vaksin dan antibiotik. Namun demikian, vaksin bersifat spesifik yaitu efektif terhadap patogen tertentu. Vaksin juga belum banyak tersedia, dan walaupun sudah ada harganya cukup mahal. Antibiotik sudah lama digunakan dalam pengobatan penyakit ikan. Namun saat ini telah ditemukan bahwa penggunaan antibiotik secara berkelanjutan dan bahan-bahan kemoterapi lainnya dapat menyebabkan resistensi mikroorganisme patogen serta terakumulasi pada ikan dan lingkungannya. Upaya pencegahan lain dapat dilakukan dengan menggunakan imunostimulan. Raa (2000) menyatakan imunostimulan merupakan suatu bahan yang dapat meningkatkan sistem kekebalan non spesifik ikan, dan merupakan alternatif bagi penggunaan bahan kimia atau obat-obatan (Shalaby et.al., 2006).

Salah satu bahan alami yang dapat meningkatkan respon imun non spesifik dan pertumbuhan ikan adalah bubuk bawang putih. Menurut Kemper (2000), bawang putih adalah salah satu tanaman alami yang mengandung bahan-bahan aktif seperti senyawa sulfur: aliin, allicin, disulfida, trisulsida; Enzim seperti: Alinase, perinase; asam amino seperti arginin dan mineral seperti selenium. Allicin merupakan salah satu zat aktif yang dapat membunuh patogen (bersifat antibakteri) seperti bakteri Aeromonas (Palungkun dan Budiarti, 2001 dalam Sholikhah, 2009). Sedangkan aliin yang terkandung dalam bawah putih secara signifikan dapat meningkatkan sistem imun ikan, sehingga bawang putih dapat digunakan sebagai imunostimulan yang efesien (Kemper, 2000). Penelitian ini menggunakan bubuk bawang putih (Allium sativum) dengan dosis berbeda sebagai imunostimulan untuk meningkatkan respon imun non spesifik pada ikan mas (Cyprinus carpio L). Tujuan penelitian ini adalah untuk menetapkan dosis bawang putih yang tepat yang mampu meningkatkan sistem imun non spesifik secara optimal dan pertumbuhan pada ikan mas (Cyprinus carpio L).

\section{BAHAN DAN METODE}

\section{Hewan Uji}

Hewan uji yang digunakan adalah ikan mas (Cyprinus caprio L) sebanyak 150 ekor dengan panjang berkisar 8-12 cm dan berat ratarata 9,37 g/ekor. Ikan uji berasal dari Balai Besar Pengembangan Benih Ikan Air Tawar (BBAT) Tatelu, Kabupaten Minahasa Utara. Penelitian dilakukan di Balai Pengembangan dan Pembinaan Pembudidaya Ikan, Balai Pengendalian Hama Penyakit Ikan dan Kesehatan Lingkungan Tateli dan Labolatrium Patologi dan Klinik Penyakit Ikan Fakultas Perikanan dan Ilmu Kelautan Universitas Sam Ratulangi Manado.

\section{Bahan Uji}

Bahan uji yang digunakan adalah bawang putih dalam bentuk bubuk yang dijual secara komersial. Sedangkan pakan ikan yang digunakan adalah pelet komersial (comfeed) yang diperoleh dari tempat penjualan pakan ikan.

\section{Persiapan Pakan}

Pertama-tama bahan uji ditimbang sesuai dosis yang digunakan dalam penelitian, kemudian bubuk bawang putih tersebut dilarutkan ke dalam $100 \mathrm{ml}$ air dan dicampurkan dengan $1 \mathrm{~kg}$ pakan. Selanjutnya larutan tersebut dimasukkan ke dalam sprayer kemudian disemprotkan ke dalam pakan secara merata, lalu pakan dikeringanginkan dalam suhu ruang.

Setelah kering, pakan yang telah dicampurkan bahan uji tersebut dilapisi dengan kuning telur (coating) secara merata, lalu dikeringanginkan kembali. Pakan yang telah kering selanjutnya dimasukkan dalam kantong plastik dan disimpan dalam lemari pendingin sampai saat akan digunakan.

\section{Rancangan Percobaan}

Penelitian ini menggunakan Rancangan Acak Lengkap (RAL) dengan menggunakan 5 perlakuan dan masing-masing perlakuan memiliki 3 (tiga) ulangan. Setiap unit percobaan ditempatkan secara acak agar mendapat perlakuan yang sama atau homogen. Perlakuan yang digunakan dalam penelitian ini adalah 
sebagai berikut: A (0 g bubuk bawang putih/kg pakan), B (10 g bubuk bawang putih/kg pakan), C (20 g bubuk bawang putih/kg pakan), D (30 g bubuk bawang putih/kg pakan) dan E (40 g bubuk bawang putih/kg pakan).

\section{Prosedur Percobaan dan Pengambilan Data}

Sebelum melakukan penelitian, ikan uji dipelihara selama 2 (dua) minggu dalam bak fiber berdiameter 2 meter dan tinggi $20 \mathrm{~cm}$ yang dilengkapi dengan aerator untuk proses aklimatisasi. Selama proses aklimatisasi ikan diberi pakan pelet komersial (comfeed) dengan dosis $5 \%$ dari berat badan/hari dengan frekuensi pemberian dua kali sehari yaitu pukul pagi 08.00 dan sore 16.00 WITA. Kualitas air selama masa aklimatisasi dikontrol setiap hari agar tetap stabil, dengan cara kotoran-kotoran yang menempel pada akuarium berupa sisa pakan atau kotoran ikan dikeluarkan dengan cara penyiponan yang dilakukan setiap kali sehari sebelum pemberian pakan. Sedangakn untuk pergantian air dilakukan setiap 2-3 hari sekali tergantung pada kondisi air dengan volume pergantian air sebanyak 30\%.

Setelah proses aklimatisasi selesai, ikan dipindahkan ke dalam akuarium kaca berukuran $80 \mathrm{~cm} \mathrm{x} 40 \mathrm{~cm} \times 40 \mathrm{~cm}(\mathrm{p} \times \mathrm{l} \times \mathrm{t})$ dengan kepadatan 15 ekor/akuarium, namun sebelumnya dilakukan penimbangan berat awal. Setiap akuarium dilengkapi dengan aerator. Pemberian pakan perlakuan berlangsung selama 4 minggu.

Selama masa percobaan, ikan diberi pakan dengan dosis $5 \%$ dari berat badan/hari dengan frekuensi pemberian pakan 2 (dua) kali sehari pada pagi pukul 08.00 dan sore pukul 16.00 WITA. Selama masa pemberian pakan perlakuan, kualitas air tetap dijaga dalam kondisi yang baik dengan cara yang sama pada saat aklimatisasi yaitu penyiponan kotoran yang menempel dan mengendap di dasar akuarium dibersihkan serta pergantian air sebanyak 30\%. Penyiponan dilakukan pada jam 07.00 dan 15.00 WITA sebelum pemberian pakan.

Data yang dikumpulkan dalam penelitian terdiridari data parameter imun dan pertumbuhan mutlak ikan mas.

\section{Parameter Imun}

Untuk pengamatan parameter imun maka diperlukan pengambilan sampel darah ikan. Pengambilan sampel dilakukan dengan menggunakan jarum suntik (spuit) yang berukuran $1 \mathrm{ml}$. Sebelum digunakan, spuit dibilas terlebih dahulu dengan heparin sebagai antikoagulan untuk mencegah terjadinya pembekuan darah. Larutan heparin (SigmaAldrich \#H4784) disiapkan dengan cara melarutkan $50 \mathrm{mg}$ bubuk heparin dalam $50 \mathrm{ml}$ akuades, kemudian disaring dengan filter membran 0,2 $\mu \mathrm{m}$. Persiapan heparin ini dikerjakan sesuai petunjuk perusahaan. Pengambilan darah dilakukan dengan cara sebagai berikut : pertama-tama ikan dalam akuarium ditangkap menggunakan seser dan dipindahkan dalam ember kecil, lalu dibawa ke dalam laboratorium. Selanjutnya ikan dalam ember ditangkap menggunakan tangan dan kemudian tubuh ikan dikeringkan dengan tissue kering lalu ditimbang untuk mendapatkan data berat tubuh. Setelah itu dilakukan pengambilan darah melalui vena caudalis. Apabila jarum tepat mengenai vena akan terlihat percikan darah yang masuk dalam spuit kemudian dilakukan penyedotan dengan cara menarik gagang spuit. Sampel darah diambil dari 1 ekor/ulangan sebanyak 0,5 ml dan pengambilannya dilakukan setiap minggu sekali. Darah yang telah diambil kemudian dimasukkan dalam eppendorf yang sebelumnya telah dibilas dengan heparin (SigmaAldrich \#H4784).

Pengambilan sampel darah dilakukan dalam seminggu sekali setelah pemberian pakan perlakuan yaitu hari ke-7, 14, 21 dan 28. Adapun parameter imun yang diamati dalam penelitian ini adalah menghitung total leukosit dan aktivitas fagositosis.

\section{a. Total Leukosit}

Untuk menghitung total leukosit, maka pertama-tama diambil $50 \mu \mathrm{l}$ dimasukkan dalam eppendorf, selanjutnya ditambahkan larutan Turk's sebanyak $500 \mu \mathrm{l}$ (perbandingan 1:10). Larutan tersebut dihomogenkan dengan cara mengayunkan tabung eppendorf secara perlahanlahan dan larutan diinkubasi selama 3-5 menit 
pada suhu ruang. Sebelum dilakukan perhitungan, larutan diambil dengan menggunakan pipet lalu diletakkan pada haemacytometer. Larutan pada bagian atas eppendorf dibuang, lalu tetesan berikutnya diteteskan pada sisi cover glass yang menutupi haemacytometer sehingga larutan akan menyebar menutupi permukaan haemacytometer. Penghitungan leukosit dilakukan dengan bantuan mikroskop pada pembesaran 40 kali. Jumlah sel leukosit yang dihitung diambil secara acak dari tiga kotak. Perhitungan total leukosit menggunakan rumus sebagai berikut:

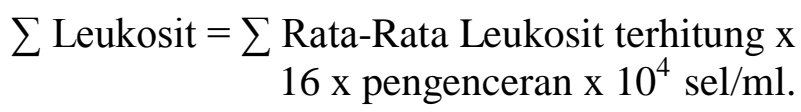

\section{b. Aktivitas Fagositosis}

Pengukuran aktivitas fagositosis dilakukan dengan cara mengambil darah sebanyak $50 \mu \mathrm{l}$ lalu dimasukkan dalam tabung eppendorf dan ditambahkan $50 \mu$ l suspensi zymosan. Proses pembuatan zymosan berdasarkan metode dari Scott dan Klesius dalam Stolen et al., (1900). Zymosan 50 mg dimasukkan dalam tabung Hush yang sudah diisi dengan $5 \mathrm{ml}$ HBSS. Tabung ditutup dan direndam dalam air mendidih selama 30 menit sambil digoyang-goyangkan agar zymosan dapat larut dengan sempurna. Setelah dipanaskan dimasukkan dalam tube plastik dan disentrifuse pada kecepatan $600 \mathrm{rpm}$ selama 5 menit. Presipitat yang terbentuk ditambahkan dengan $10 \mathrm{ml}$ HBSS dan disentrifuse pada kecepatan 600 rpm selama 5 menit (dilakukan sebanyak 2 kali). Supernatan yang terbentuk dibuang dan presipitat disuspensikan ke dalam $50 \mathrm{ml}$ HBSS untuk memperoleh konsentrasi 1 $\mathrm{mg} / \mathrm{ml}$. Selanjutnya darah dihomogenkan dengan cara mengayunkan tabung eppendorf secara perlahan-lahan dan diinkubasi dalam suhu ruang selama 20 menit. Sampel darah diambil sebanyak $5 \mu \mathrm{l}$ untuk membuat preparat ulas dan dikeringanginkan.

Sediaan ulas yang telah kering, diwarnai (stainning) dengan prosedur sebagai berikut (Pritchard and Kruse, 1982):
1. Sediaan ulas direndam dalam alkohol $95 \%$ selama 1 menit.

2. Diamkan beberapa saat sehingga alkohol menguap dari preparat (tetapi preparat masih dalam keadaan basah).

3. Preparat direndam dalam larutan Giemsa (Sigma-Aldrich) selama 10 menit.

4. Selanjutnya secara perlahan-lahan preparat dibilas dengan air mengalir kemudian dikeringkan.

Setelah sediaan ulas kering, dilakukan pengamatan di bawah mikroskop cahaya dengan pembesaran 100 kali. Jumlah sel yang menunjukkan proses fagosistosis dihitung dari 50 sel fagosit yang teramati. Aktivitas fagositosis dihitung dengan formula :

Aktivitas Fagosit $(\%)=$

$\left\{\frac{\text { (Jumlah sel fagosit yang melakukan fagositosis) }}{\text { Jumlah sel fagosit teramati }}\right\}$ x100

\section{Pertumbuhan Mutlak}

Penimbangan berat ikan untuk mendapatkan pertumbuhan mutlak dilakukan pada akhir penelitian yaitu pada akhir minggu keempat. Pertumbuhan mutlak dinyatakan sebagai selisih berat ikan yang diukur pada akhir penelitian dengan berat ikan pada awal penelitian. Pertumbuhan mutlak dihitung dengan formula ( Efendie 1979).

Ket:

$$
\Delta \mathbf{G}=\mathbf{W}_{\mathbf{t}}-\mathbf{W}_{\mathbf{0}}
$$

$$
\begin{aligned}
\Delta \mathrm{G}= & \text { Pertumbuhan }(\mathrm{g}), \\
\mathrm{Wt}= & \text { Berat ikan pada waktu } \mathrm{t}(\mathrm{g}), \\
\mathrm{Wo}= & \text { Berat rata-rata pada awal } \\
& \text { percobaan }(\mathrm{g}) .
\end{aligned}
$$

\section{Analisis Data}

Data yang diperoleh dinyatakan dalam bentuk nilai rata-rata \pm Stdv (standar deviasi). Untuk melihat apakah perlakuan yang diberikan berpengaruh terhadap respon imun, maka dilakukan analisis ragam. Sedangkan untuk melihat perbedaan pengaruh antar perlakuan maka dilakukan uji Duncan menggunakan alat bantu SPSS untuk windows. 


\section{HASIL DAN PEMBAHASAN}

\section{Respon Imun Non Spesifik}

\section{a. Total Leukosit}

Hasil penghitungan rata-rata total leukosit ikan mas dengan penambahan bawang putih pada perlakuan A (0 g/kg pakan), perlakuan B (10 g/kg pakan), perlakuan C (20 g/kg pakan), perlakuan D (30 g/kg pakan) dan perlakuan E (40 g/kg pakan) selama penelitian dapat dilihat pada Gambar 1

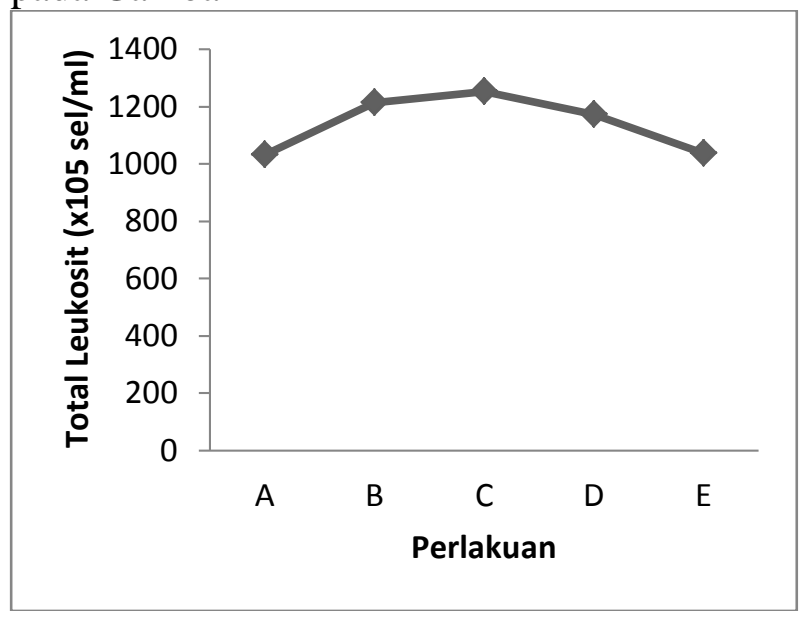

Gambar 1. Histrogram rata-rata total leukosit $\left(\mathrm{x} 10^{5} \mathrm{sel} / \mathrm{ml}\right)$ ikan mas setelah diberi pakan perlakuan pada minggu ke- 4 .

Jumlah rata-rata total leukosit tertinggi dicapai pada perlakuan C $\left(1253,33 \pm 21,33 \times 10^{5}\right.$ $\mathrm{sel} / \mathrm{ml})$, diikuti berturut-turut $\mathrm{B}(1214,22 \pm 57,52$ $\left.\mathrm{x} 10^{5} \mathrm{sel} / \mathrm{ml}\right), \mathrm{D}\left(1171,55 \pm 29,37 \times 10^{5} \mathrm{sel} / \mathrm{ml}\right), \mathrm{E}$ $\left(1036,44 \pm 511 \quad \mathrm{x} 10^{5} \mathrm{sel} / \mathrm{ml}\right)$ dan A $\left(1031.11 \pm 85.38 \times 10^{5} \mathrm{sel} / \mathrm{ml}\right)$.

Selanjutnya hasil analisis ragam menunjukkan bahwa pemberian pakan dengan penambahan bubuk bawang putih setelah diberikan selama 4 minggu berpengaruh sangat nyata $(\mathrm{p}<0,01)$ terhadap peningkatam total leukosit. Hasil uji lanjut Duncan memperlihatkan bahwa setelah diberikan selama 4 minggu, perlakuan C, perlakuan B dan D berbeda nyata dibandingkan dengan perlakuan A dan perlakuan E, tetapi antar perlakuan C, B dan E tidak terdapat perbedaan nyata. Secara kuantitatif total leukosit ikan yang diberi perlakuan C lebih banyak dibandingkan dengan perlakuan B dan D.

Hasil penelitian memperlihatkan bahwa penambahan bubuk bawang putih dapat meningkatkan total leukosit pada ikan mas dimana nilai tertinggi dicapai pada perlakuan $\mathrm{C}$ yaitu $1253.33 \pm 21.33 \times 10^{5} \mathrm{sel} / \mathrm{ml}$. Jumlah leukosit yang ada pada suatu jenis ikan tertentu dapat berubah sesuai dengan tingkat kesehatan ikan yang bersangkutan. Apabila ikan terinfeksi oleh suatu bakteri patogen tertentu maka yang akan terjadi selanjutnya pada ikan tersebut adalah meningkatnya jumlah total leukosit atau menurunnya jumlah leukosit. Ikan yang kekurangan jumlah leukosit menjauhi batas normalnya akan menderita penyakit leucopenia (Robert, 1978 dalam Anonim, 2013). Jumlah leukosit normal pada ikan mas berkisar antara 16.240-24.620x10 ${ }^{3} \mathrm{sel} / \mathrm{mm}^{3}$ (Anonim, 2013). Selanjutnya Salasia et al., (2001) dalam Nuryati dkk., (2008) melaporkan jumlah leukosit dalam darah ikan mas berkisar 3.390-14.200 sel/ $/ \mathrm{mm}^{3}$.

Dalam penelitian yang dilakukan oleh Fazlolahzadeh et al., (2011), ikan rainbow trout yang diberi pakan dengan penambahan 40 gram/kg pakan bawang putih memiliki jumlah leukosit yang lebih tinggi dibandingkan dengan ikan kontrol maupun dengan ikan yang diberi 20 dan $30 \mathrm{gram} / \mathrm{kg}$ pakan. Selanjutnya Nya and Austin (2009) menyatakan bahwa ikan rainbow trout dengan penambahan bawang putih 10 gram/kg pakan memiliki jumlah leukosit yang lebih banyak dibandingkan dengan ikan yang tidak diberikan bawang putih.

\section{b. Aktivitas Fagositosis}

Nilai aktivitas fagositosis rata-rata ikan mas setelah diberi pakan dengan penambahan bawang putih selama empat minggu berturutturut dapat dilihat pada Gambar 2. 


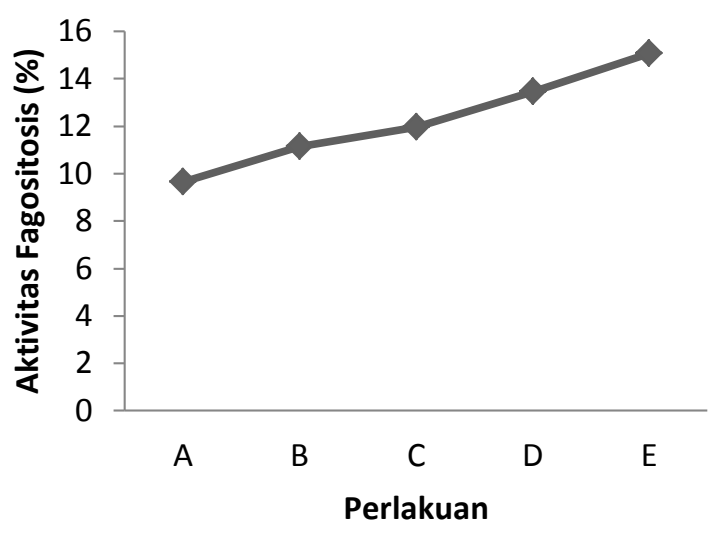

Gambar 2. Histrogram rata-rata aktivitas fagositosis ikan mas setelah diberi pakan perlakuan pada minggu ke- 4 .

Nilai rata-rata aktivitas fagositosis pada minggu keempat cenderung meningkat yaitu pada perlakuan E mencapai nilai $15.07 \pm 0.45 \%$, perlakuan D (13.44 $\pm 1.16 \%)$, perlakuan C (11.97 $\pm 2.08 \%)$, perlakuan B $(11,14 \pm 1.41 \%)$ dan nilai terendah pada perlakuan A $(9.65 \pm 1.23 \%)$.

Dalam penelitian ini nilai aktivitas fagositosis tertinggi dicapai pada dosis yang tinggi yaitu 30-40 g/kg pakan. Dalam penelitian yang dilakukan oleh Nya and Austin et al., (2009), ikan rainbow trout berukuran rata-rata 15 g/ekor yang diberi pakan dengan penambahan 10 gram bawang putih per kilogram pakan memiliki aktivitas fagositosis yang lebih tinggi dibandingkan dengan ikan kontrol.

Hasil analisis ragam memperlihatkan bahwa pemberian bawang putih berpengaruh sangat nyata terhadap actifitas fagositosis $(\mathrm{p}<0.01)$. Hasil uji lanjut Dancun memperlihat bahwa pada minggu keempat perlakuan E dan D berbeda sangat nyata dibandingkan dengan perlakuan A namun antar perlakuan E dan D tidak berbeda nyata.

Hasil penelitian ini membuktikan bahwa penambahan bawang putih dalam pakan ikan mampu meningkatkan aktivitas fagositosis. Hasil penelitian ini juga memperlihatkan bahwa aktivitas fagositosis semakin meningkat sejalan dengan meningkatnya dosis bawang putih. Bawang putih dapat meningkatkan aktivitas fagositosis ikan sebab salah satu bahan yang terkandung dalam bahan ini adalah diallil disulfide. Menurut Nuryati, et al., (2008), diallil disulfide mampu meningkatkan kekebalan non spesifik dengan cara meningkatkan aktivitas fagositosis dan merangsang aktivitas sel yang berperan dalam respon imun.

\section{Pertumbuhan Mutlak}

Hasil perhitungan pertumbuhan mutlak ikan mas dapat dilihat pada Gambar 3.

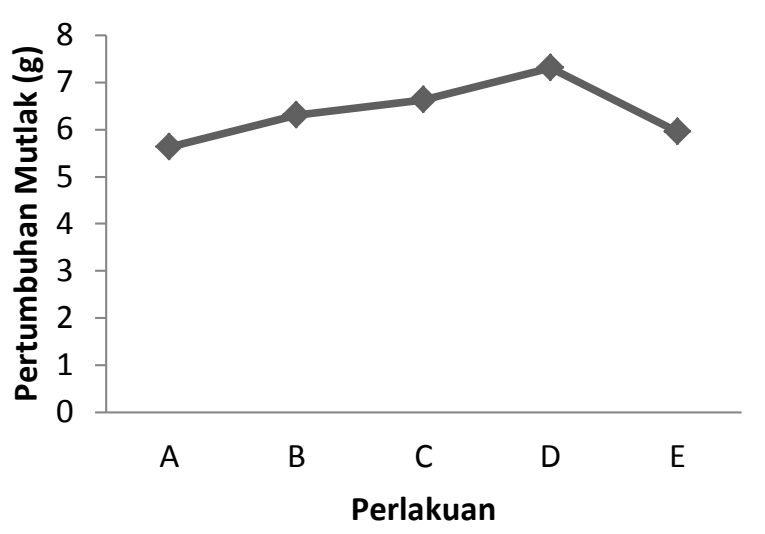

Gambar 3. Histrogram pertumbuhan mutlak ratarata ikan mas setelah diberi pakan perlakuan selama 4 minggu

Nilai rata-rata perhitungan pertumbuhan mutlak, menunjukkan bahwa ada kecenderungan peningkatan pertumbuhan pada perlakuan A (0 g/kg pakan), B (10 g/kg pakan), C (20 g/kg pakan) dan D (30 g/kg pakan) namun pada perlakuan E (40 g/kg pakan) menurun. Dari hasil penelitian diketahui bahwa penambahan bawang putih dalam pakan ikan dengan dosis $30 \mathrm{~g} / \mathrm{kg}$ pakan mampu meningkatkan pertumbuhan mutlak ikan mas yakni berkisar 6,63-8,63 g.

Aly e.al., (2008) mendapatkan ikan nila yang diberi pakan dengan penambahan bawang putih 10 gram $/ \mathrm{kg}$ pakan memiliki pertumbuhan yang lebih baik dibandingkan dengan kontrol jika diberikan selama 1 bulan, namun apabila diberikan selama dua bulan pertumbuhan ikan tidak berbeda dengan penambahan bawang putih 20 gram/kg pakan dan 30 gram/kg pakan. Dalam penelitian oleh Shalaby e.al., (2006), ikan nila yang diberikan pakan dengan penambahan 
bawang putih 30 gram $/ \mathrm{kg}$ pakan memiliki pertumbuhan terbaik dibandingkan dengan perlakuan kontrol dan perlakuan lainnya.

Hasil penelitian mendapatkan bahwa penambahan bubuk bawang putih pada perlakuan B (10 g/kg pakan), C (20 g/kg pakan) dan D (30 g/kg pakan) memberikan pengaruh yang sama terhadap peningkatan total leukosit ikan mas sedangkan pada aktivitas fagositosis perlakuan D (30 g/kg pakan) dan E (40 g/kg pakan) mempunyai pengaruh yang sama. Oleh karena itu dapat disimpulkan bahwa penggunaan bawang putih pada dosis $30 \mathrm{~g} / \mathrm{kg}$ pakan merupakan dosis terbaik yang dapat digunakan untuk meningkatkan respon imun maupun pertumbuhan ikan mas.

\section{Parameter Kualitas Air}

Parameter kualitas air yang diamati adalah suhu, pH dan DO (oksigen terlarut). Hasil pengukuran suhu air selama penelitian berkisaran $28-30{ }^{\circ} \mathrm{C}$, derajat keasaman air $(\mathrm{pH})$ berkisar antara $6.9-7.2$ dan DO berkisar antara 5.2 - 5.4 ppm. Mantau dan Sumarty (2011) menyatakan bahwa ikan mas hidup pada suhu berkisar $20-30{ }^{0} \mathrm{C}$, pH berkisar 7-8 dan kandungan oksigen terlarut lebih besar 5 ppm. Kualitas air selama penelitian menunjukkan layak untuk kehidupan ikan mas.

\section{KESIMPULAN}

1. Pemberian bawang putih dalam pakan mampu meningkatkan respon imun non spesifik pada ikan mas.

2. Penambahan bubuk bawang putih dalam pakan sebanyak 30 gram/kg pakan dapat meningkatkan total leukosit dan aktivitas fagositosis maupun pertumbuhan ikan mas.

\section{DAFTAR PUSTAKA}

Afriyanto, E., Liviawaty, E. 2006.

Pengedalian Hama dan Penyakit Ikan.

Penerbit Kansius. Yogyakarta.

Aly, S. H., Mohammed, M. H., George, J.,
2008. Echinacea as Imunostimulatory Agent In Nile Talapia (Oreochromis niloticus) Via Earthen Pond Axperiment.

Anonimous. 2013. Menentukan Jumlah Leukosit Pada Ikan. http://www.docstoc. com/docs/125719968/Menentuknjumlah-leukosit-pada-ikan. Diaksses 22 Januari 2013 13:00 Wita.

Effendie.M.I. 1979. Metoda Biologi Perikanan. Yayasan Dwi Sri. Bogor.

Fazlolahzadeh, F., Keramati, K. S., Nazifi,. Shirian, S. S., Seifi, 2011. Effect of Garlic (Allium sativum) on Hematological Parameters and Plasma Activities of ALT and AST of Rainbow trout in Temperature Stress. Australian Journal of Basic and Applied Sciences, 5(9): $84-90$

Kemper, K. J. 2000. Garlic (Allium sativum). Longwood Herbal Task Force. Mantua. Z dan Sudarty. 2011. Buku Terlengkap Pembenihan Ikan Mas Yang Efektif dan Efisien. Pustaka Mina. Depok Timur.

Nuryati. S. Giri dan Hadiroseyani. 2008.

Efektivitas Ekstrak Bawang Putih (Allium sativum) Terhadap Ketahanan Tubuh Ikan Mas (Cyprinus carpio) Yang Diinfeksi Koi Herpes Virus (KHV). IPB Bogor. Bogor.

Nya, E. J and Austin. 2009. Use of Garlic, Allium sativum, To Control Aeromonas hydrophila infection in rainbow trout, Oncorhynchus Mykiss (Walbaum). University of Stirling, Stirling. UK.

Pritchard, M. H. and Kruse, G. O. W. 1982. The Collection and Preservation of Animal Parasites. University of Nebraska Press. London.

Raa, J., 2000. The use of immune-stimulants in fish and shellfish feeds. In: Cruz -Suárez, L.E., Ricque-Marie, D., Tapia-Salazar, M., Olvera-Novoa, M.A. y CiveraCerecedo, R., (Eds.). Avances en Nutrición Acuícola V. Memorias del V Simposium Internacional de Nutrición Acuícola. Mérida, Yucatán, Mexico. 
Shalaby, A. M, Khattab, Y. A,. and Rahman, A. (2006). Effects Of Garlic (Allium sativum) And Chloramphenicol On Growth Performance, Physiological Parameters and Survival Of Nile Talapia (Oreochromis niloticus). J. Venom. Anim. Toxins incl. Trop. Dis.

Sholikhah. E.H. 2009. Efektivitas Campuran Meniran Phyllanthun niruri dan Bawang Putih (Allium sativum) DalamPakan Untuk Pengendalian Infeksi Bakteri Aeromonas hydrophila Pada Ikan Lele Dumbo (Clarias sp). (Skripsi). IPB, Bogor.
Stolen, S.S., Fletcher, T.C. Andreson, D.P D.S. Roberson, W.B. Van Muiswinkel (eds.). 1990. Techniques in Fish Immunology. SOS Publications. 43 De Normandie Ave, Fair 